\title{
Sceptical Theism and the Paradox of Evil ${ }^{1}$
}

\author{
Luis R. G. Oliveira \\ University of Houston
}

\begin{abstract}
Given plausible assumptions about the nature of evidence and undercutting defeat, many believe that the force of the evidential problem of evil depends on sceptical theism being false: if evil is evidence against God, then seeing no justifying reason for some particular instance of evil must be evidence for it truly being pointless. I think this dialectic is mistaken. In this paper, after drawing a lesson about fallibility and induction from the preface paradox, I argue that the force of the evidential problem of evil is compatible with sceptical theism being true. More exactly, I argue that the collection of apparently pointless evil in the world provides strong evidence for there being truly pointless evil, despite the fact that seeing no justifying reason for some particular instance of evil is no evidence whatsoever for it truly being pointless. I call this result the paradox of evil.
\end{abstract}

Keywords: Evidential Problem of Evil, Sceptical Theism, Fallibility, Induction

\section{Introduction}

The undeniable existence of evil in our world is a springboard for some of the most powerful arguments for atheism. These arguments come in different versions. According to the logical problem of evil, the mere existence of any evil whatsoever is logically incompatible with the existence of a perfect God. According to the evidential problem of evil, the existence of evil gives us sufficient evidence against the existence of such a God, despite being logically compatible with it. The latter version is more modest, and it itself comes in different formulations. According to one formulation, originally due to William Rowe [1979], it is the existence of a specific kind of evil_apparently pointless suffering-which gives us evidence against the existence of God. My focus in this paper is on this particular formulation of the evidential version of the problem of evil.

After Rowe, we can formulate the problem of evil in the following way:

\section{The Evidential Argument from Evil (EAE)}

P1. After careful reflection on our experience and knowledge, we see no justifying reason for many instances of suffering in the world.

\footnotetext{
1 This paper is dedicated to my undergraduate advisor, and now friend, Steve Wykstra. For helpful comments and discussions, I am also grateful to Hilary Kornblith, Timothy Perrine, Joshua DiPaolo, Benjamin McCraw, Aaron Washington, Joe Milburn, Brendan de Kenessey, Heidi Furey, Scott Hill, Kristian Olsen, Bob Gruber, Christopher Phillips, Sérgio Miranda, Agnaldo Portugal, Alcino Bonella, Marciano Spica, Nathan Biebel, audiences at the University of Massachusetts Amherst, at Kansas State University, at the Universidade Federal de Ouro Preto (Brazil), at the 2017 meeting of the Society for Exact Philosophy, at the 2018 meeting of the Eastern APA, and three anonymous referees.
} 
P2. If, after careful reflection on our experience and knowledge, we see no justifying reason for many instances of suffering in the world, then it is reasonable to believe that there is no justifying reason for at least some of all that suffering.

P3. So it is reasonable to believe that there is no justifying reason for at least some of the suffering in the world.

P4. If there is even one instance of suffering for which there is no justifying reason, then God does not exist.

C. So it is reasonable to believe that God does not exist. ${ }^{2}$

A justifying reason, in this case, is some consideration in favour of allowing the relevant instance of suffering that would mitigate its existence-it furthers or respects a greater good; it prevents a comparable or greater evil; preventing it violates some deontological constraint; and so on. The notion of a justifying reason is in fact quite ordinary. Suppose a parent is deciding on whether to get her child vaccinated. Though this will be an instance of suffering, a justifying reason is readily available: this instance of suffering will significantly lower the chances of much worse suffering in the future. EAE simply exploits the common impression that we are unable to produce some such justifying reason for so much of the suffering that we see around us.

Given plausible assumptions about the nature of evidence and undercutting defeat, however, many believe that the force of this argument depends on sceptical theism being false. According to sceptical theism, it is not at all likely that we would see the justifying reasons for the instances of suffering we see around us, were God and such reasons to really exist. There is just too great a gap between our cognitive capacities and God's; we cannot expect to see all the goods, and all the connections between goods and evils, for example, that He sees. The tension between the evidential problem of evil and sceptical theism is then clear: if we cannot expect to see God's justifying reasons in the first place, then how could not seeing them provide us with evidence against God? The force of EAE, it seems, hangs in the balance.

But I believe this dialectic is mistaken. In this paper, I argue that we may construe the evidential version of the problem of evil in general, and EAE in particular, as compatible with sceptical theism. I begin by showing that sceptical theism blocks the evidential problem of evil only given certain natural assumptions about how the evidence from evil accrues (Section 2). I then show that these assumptions are not essential to the statement of the problem, and I show which alternative

\footnotetext{
${ }^{2}$ This is an extended version of the argument Rowe [1979: 336] states explicitly. It includes Rowe's [1979: 337-338] defence of his argument as premises 1 and 2, and it incorporates his later qualifications to the strength of the argument.
} 
assumptions can take its place (Sections 3 and 4). I conclude with a defence of these alternative assumptions (Section 5).

I am not the first one, of course, to suggest that the evidential problem of evil survives sceptical theism. Some suggest that the evidential problem of evil survives because sceptical theism is false: it is just not true that seeing no justifying reason for an instance of apparently pointless suffering gives us no evidence against God. ${ }^{3}$ Others suggest that the evidential problem of evil survives because sceptical theism is irrelevant to some of its different formulations. ${ }^{4} \mathrm{My}$ argument in this paper constitutes an importantly different approach. My claim is that the very same formulation of the evidential problem of evil that is under attack by sceptical theism can survive that attack even if sceptical theism is true. If I am right about this, then a major stalemate can be altogether sidestepped.

\section{The inductive Justification and Sceptical Theism}

The heart of the evidential problem of evil, formulated as EAE, is P2. Properly understood, P2 is in fact quite modest. It is consistent, for example, with acknowledging that there might be, for all we know, a justifying reason behind any particular instance of apparently pointless suffering. It is even consistent with it being positively unreasonable to believe, of any particular instance of apparently pointless suffering, that there is no justifying reason behind it. In other words, EAE does not depend on the evidential support that is offered by any single instance, taken by itself. Instead, EAE turns on the much stronger evidential support that is offered by adding together several instances of the kind of suffering that befuddles us. ${ }^{5}$

But there are different ways of understanding the mechanism responsible for the production of such strong evidence. On what I will call the inductive justification of P2, EAE depends on the cumulative evidential support that is gathered by enumerative induction. Taking for granted that the operative notion of evidential support is probabilistic (and that the normative status of 'reasonable belief' supervenes on the strength of one's evidence), the picture is something like the following. First, after

\footnotetext{
3 See, for example, Rowe [1991, 1996, 2006], Dougherty [2012], and Hudson [2014].

${ }^{4}$ See, for example, Draper [1989, 2009], Dougherty [2008], and Tooley [2012].

5 This aspect of EAE is too often ignored. Thus van Inwagen [2001: 69]: 'I will now construct a version of the argument from evil, a version that makes reference only to this one event, this one horror, and not to the general or global fact that the world contains vast amounts of horrendous evil. (The argument is modeled on the central argument of William Rowe's "The Problem of Evil and Some Varieties of Atheism.")'. But notice the progression of Rowe's [1979: 337] original reasoning, from the 8th paragraph (where he introduces his famous fawn example as an instance of apparently pointless suffering), into the 9th paragraph (where he grants that there might be a justifying reason behind the fawn example that we just can't see), through the 10th paragraph (where he suggests that we shouldn't look for a proof for the belief in pointless evil but rather for its rational grounds), to the 11th paragraph (where he finally rests his argument on an inference from the large sample of apparently pointless evil that we see).
} 
seeing no justifying reason for a single instance of suffering $\left(e_{1}\right)$, the belief that there is no justifying reason for at least some instances of suffering (h) becomes a bit more likely for me. In such cases, $\mathrm{e}_{1}$ is evidence for me that h. Second, after seeing no justifying reason for a handful of such instances $\left(e_{1}\right.$, $\left.\mathrm{e}_{2}, \mathrm{e}_{3}\right)$, that same belief becomes even more likely to be true. In such cases, I have more evidential support for that belief than I had before. Third, after seeing no justifying reason for very many instances of apparently pointless suffering, belief in $\mathrm{h}$ receives enough evidential support to rise up to the status of being reasonable. In such cases, $\left(e_{1} \wedge e_{2} \wedge e_{3} \wedge \ldots e_{n}\right)$, together, constitute sufficient evidence for me that $h$.

According to the inductive justification, then, even though P2 licenses as reasonable only a belief that is based on the cumulative evidential support of many instances of apparently pointless suffering, EAE nonetheless depends on the fact that each particular instance carries some evidential weight of its own. This suggests that EAE stands or falls with the following claim:

(Instance) S's seeing no justifying reason for an instance of suffering is evidence for $\mathrm{S}$ that there is no justifying reason for at least some instances of suffering.

It also suggests that challenging (Instance) undermines the admittedly more complex P2 and, consequently, EAE itself.

As it turns out, and perhaps surprisingly, the most common reply to EAE targets precisely this inductive justification of P2. ${ }^{6}$ The position licensing a denial of this seemingly modest claim about what's reasonable to believe given a large sample, after careful reflection on our experience and knowledge, results from conjoining a claim about the nature of undercutting defeat and a claim about our limited epistemic position. Call this resulting position sceptical theism:

Sceptical Theism: Seeing no justifying reason for an instance of suffering is not evidence for us that such a reason is not there.

Thus formulated, notice, sceptical theism entails the very denial of (Instance). ${ }^{7}$

\footnotetext{
${ }^{6}$ Dougherty and Pruss [2014: 68] claim that what I am calling (Instance) is 'essentially the core of the original version of Rowe's famous reading of the argument from evil'. The literature seems to agree. See, for example, Wykstra [1984: 82-3, 1996: 128], Otte [2000: 5-8], Bergmann and Rea [2005: 241], and Wielenberg [2015: 304].

7 Sceptical Theism is here a claim about the total defeat of the evidential import of evil: once we appreciate the limits of our epistemic position, we see that instances of apparently pointless evil do not increase the likelihood of there being truly pointless evil [cf. Wykstra 1984: 78-9; Bergmann 2008: 387-8; Otte 2012: 127]. This is the original, most forceful, and still most widely debated version of sceptical theism. Recently, however, sceptical theism has also been formulated as a more
} 
We can state the claims jointly offered in support of sceptical theism more carefully as follows:

(Expectation) If we cannot expect to see something, were it to be there, then our not seeing it is not evidence for us that it is not there.

(Limitation) We cannot expect to see a justifying reason for instances of apparently pointless suffering, were such reasons to be there.

And we can illustrate the appeal of these claims with some examples [cf. Wykstra 1996: 129-30]. Suppose you are wondering whether a certain hypodermic needle, about to go into your arm, is contaminated. Suppose your doctor, trying to comfort you, fixes her stare on the needle while saying 'I see no viruses on this needle'. Is her experience any evidence for her that the needle is virus-free? Does her seeing no viruses on the needle increase the likelihood for her that there are no viruses on the needle? Not only is the answer to these questions 'no', (Expectation) seems to be their explanation. It is precisely because the doctor cannot expect to see any viruses, were there any on the needle in the first place, that seeing no virus falls short of being evidence against that claim. Now consider once again the parent who allows her child one bit of suffering on the basis of the justifying reason of preventing much worse suffering in the future. Given the epistemic position of the child, in relation to the epistemic position of her parent, she cannot expect to see the justifying reason on the basis of which her parent is allowing her that mystifying bit of pain. (Limitation), then, is simply the plausible claim that our epistemic position in relation to God's is similar to that child's epistemic position in relation to her parent's. Just as the child, we cannot expect to see God's justifying reasons for allowing the many apparently pointless bits of suffering that we see, were any such reasons to truly be there. ${ }^{8}$

It is now easy to see why many believe that the force of EAE depends on sceptical theism being false. If sceptical theism is true, then (Instance) is false; if (Instance) is false, then the inductive justification for P2 is undermined. Though EAE aims to show merely that it is reasonable to be an atheist—on the basis of the evidence provided by adding together very many instances of apparently

modest claim about the partial defeat of the evidential import of evil: apparently pointless evil may well increase the likelihood of there being truly pointless evil, but never enough to make it reasonable for belief [cf. Wykstra and Perrine 2012: 384]. I will not consider this unorthodox version here.

${ }^{8}$ For endorsements of (Expectation), see Wykstra [1984: 85], Plantinga [2000: 466], and Howard-Snyder and Bergmann [2004: 16]. For endorsements of (Limitation), see Wykstra [1996: 135-7], Bergmann [2001: 279], Howard-Snyder [2009: 18], and Long [2014: 65-66]. 
pointless suffering-sceptical theism seems to show that EAE fails even in the modest task that was its charge. ${ }^{9}$

\section{Non-Cummulative Inductive Bases}

Leaving aside debates over sceptical theism, I will now argue that there is a justification available for P2 that does not depend on (Instance). On what I will call the collective justification of P2, EAE does not depend on there being some modicum of evidential support provided by particular instances of apparently pointless suffering. The key to understanding this justification is seeing how apparently pointless evil produces what I will call a non-cumulative inductive base. In this section, I identify and clarify the nature of these inductive bases. In the next, I apply them to the evidential problem of evil in particular.

Consider the preface paradox. The preface paradox arises in cases where we reasonably believe of each claim in a collection that it is true and yet are unreasonable in believing of the collection itself that it does not contain at least one claim that is false [cf. Makinson 1965]. A book provides a common instance of these kinds of cases: though the careful and responsible writer reasonably believes every claim that she makes, it would be presumptuous to believe that she has made no mistake throughout. Hence the common confession found in prefaces, after the acknowledgement of the positive influence of friends and peers, that 'any mistakes are wholly mine'. Common as they are, these cases seem paradoxical since they violate a very plausible principle of aggregation (PP1 below). More carefully, the preface paradox can be stated in the following way:

\section{The Preface Paradox}

PP1. If I reasonably believe that $\mathrm{p}_{1}$ is true, and I reasonably believe that $\mathrm{p}_{2}$ is true, then it is reasonable for me to believe that $\left(\mathrm{p}_{1} \wedge \mathrm{p}_{2}\right)$ is true as well.

PP2. I reasonably believe that $\mathrm{p}_{1}$ is true, I reasonably believe that $\mathrm{p}_{2}$ is true, ... I reasonably believe that $\mathrm{p}_{\mathrm{n}}$ is true.

PP3. It is not reasonable for me to believe that $\left(\mathrm{p}_{1} \wedge \mathrm{p}_{2} \wedge \ldots \mathrm{p}_{\mathrm{n}}\right)$ is true.

These three claims cannot all be true. Yet we seem to have instances-choose any carefully written monograph-where all three seem true nonetheless.

\footnotetext{
${ }^{9}$ For resistance to (Limitation), see Rowe [1991: 73, 1996: 272, 2006: 88-91], and Dougherty [2012: 21-23]. For resistance to (Expectation), see Dougherty [2008: 176], and Benton, Hawthorne, and Isaacs [2016: 15-16].
} 
Few attempts to solve this paradox take aim at either PP2 or PP3. It seems exceedingly plausible that these are true, and turning to degrees of confidence is a common way of making a case for them. Suppose I am properly confident in each of the claims I make in my book. I am 95\% confident that $\mathrm{p}_{1}$, and $95 \%$ confident that $\mathrm{p}_{2}$, and so on. This suggests that I am reasonable in believing that each of them is true: each of them, as far as I can tell, is extremely likely to be true. Hence PP2. Yet no matter how properly confident I am in each of my claims individually, the probability calculus ensures that their conjunction remains wildly unlikely, as long as they are independent of each other. At 95\% confidence, we need to conjoin only 15 independent claims before their likelihood, together, is very low: $\left(\mathrm{p}_{1} \wedge \mathrm{p}_{2} \wedge \ldots \mathrm{p}_{15}\right)=.46$. This suggests that $\mathrm{I}$ am not reasonable in believing that $\left(\mathrm{p}_{1} \wedge \mathrm{p}_{2} \wedge\right.$ ... $\mathrm{p}_{\mathrm{n}}$ ) is true: the collection of these claims is extremely unlikely to be true. Hence PP3. So it seems we have good reason to resolve the preface paradox by rejecting PP1. The preface paradox remains paradoxical, therefore, only to the extent that PP1 remains unshakably plausible to you. ${ }^{10}$

There is, however, a further dimension to the preface paradox that is left unaddressed by the probabilistic resolution sketched above. Assuming, as we have, that it is my evidence which makes something reasonable or unreasonable for belief, we don't just want to know that 'it is not reasonable for me to believe that $\left(p_{1} \wedge p_{2} \wedge \ldots p_{n}\right)$ is true', we also want to know what my evidence against $\left(p_{1} \wedge\right.$ $\left.\mathrm{p}_{2} \wedge \ldots \mathrm{p}_{\mathrm{n}}\right)$ really is. One is perhaps tempted here to point to $\mathrm{p}_{1}$ and $\mathrm{p}_{2}$, and so on, since it is their conjunction that makes $\left(\mathrm{p}_{1} \wedge \mathrm{p}_{2} \wedge \ldots \mathrm{p}_{\mathrm{n}}\right)$ unlikely to be true. Yet, intuitively, it is plain false that a claim I'm confident is true is evidence for me that there is at least one false claim in my book. My proper confidence in $\mathrm{p}_{1}$ (and in $\mathrm{p}_{2}$, and so on) seems instead to make it likely that $\left(\mathrm{p}_{1} \wedge \mathrm{p}_{2} \wedge \ldots \mathrm{p}_{\mathrm{n}}\right)$ is true. As Klein [1985: 123] himself recognizes (and Ryan [1991: 296] concurs), 'in some cases the very best warranting evidence available for a conjunction is the conjuncts'. So the question remains: in preface-paradoxical cases, what is my evidence against $\left(\mathrm{p}_{1} \wedge \mathrm{p}_{2} \wedge \ldots \mathrm{p}_{\mathrm{n}}\right)$ ?

The answer turns on considering the difference between taking an individual proposition as true and taking a collection of propositions as true. Suppose I want to check whether there is a false claim in my book. Suppose the first claim I check is one I am confident is true. I shouldn't then say:

'I am confident this claim is true; so I'm now a bit more confident that there is something false in my book'.

10 Makinson [1965], Klein [1985], Foley [1993], and Christensen [2004] all reject a version of PP1. Pollock [1990], Ryan [1991], Kaplan [1996], Adler [2002], and Kim [2015] all reject versions of PP2, PP3, or their conjunction. Finally, Schechter [2013] argues that the real problem behind the preface paradox, a problem with the deductive closure of justification, re-appears even after the probabilistic resolution discussed above. 
That sounds absurd. Nonetheless, it seems perfectly correct to say that when I consider the large collection of all my claims, taken together, I thereby get evidence for there being something false in my book, even while they all seem true to me. So while an apparently true claim in my book, taken individually, is no evidence for me that there is at least one false sentence in my book (call this evidential fact $E_{1}$ ), a large number of these claims, taken as a collection, is in fact sufficient evidence for that same belief (call this evidential fact $E_{2}$ ). I want to briefly justify these two evidential facts, before drawing from them a general lesson about induction.

We can state the first evidential fact more carefully in the following way:

(E $\mathbf{E}_{1} \mathrm{p}_{1}$ does not provide me with any evidence for the claim that 'there is at least one false claim in my book' (F).

If we take, as we have, evidential relations to be simple confirmation relations-where $\mathrm{p}_{1}$ is evidence for $F$ iff $P\left(F \mid p_{1} \& k\right)>P(F \mid k)$ —we can then see that $E_{1}$ is true by appealing to a simple consequence of Bayes Theorem:

$$
\text { (T) } \mathrm{P}(\mathrm{h} \mid \mathrm{e} \& \mathrm{k})>\mathrm{P}(\mathrm{h} \mid \mathrm{k}) \text { iff } \mathrm{P}(\mathrm{e} \mid \mathrm{h} \& \mathrm{k})>\mathrm{P}(\mathrm{e} \mid \mathrm{k})
$$

This means that ' $\mathrm{p}$ ' ' is only evidence for ' $\mathrm{F}$ ' if ' $\mathrm{F}$ ' itself predicts ' $\mathrm{p}_{1}$ '. The problem, however, is that ' $\mathrm{P}\left(\mathrm{p}_{1} \mid \mathrm{F} \& \mathrm{k}\right)>\mathrm{P}\left(\mathrm{p}_{1} \mid \mathrm{k}\right)$ ' is false. Our ' $\mathrm{F}$ ' does not predict ' $\mathrm{p}_{1}$ '. Suppose I am writing a history book and that ' $\mathrm{p}$ ' is the claim that 'Napoleon lost the battle of Waterloo'. The probability of this being true is not raised by the fact that 'there is at least one false claim in my book'. So ' $\mathrm{p}_{1}$ ' is not evidence for ' $\mathrm{F}$ ' and $\mathrm{E}_{1}$ is true. Whatever role $\mathrm{p}_{1}$ may have in making $\left(\mathrm{p}_{1} \wedge \mathrm{p}_{2} \wedge \ldots \mathrm{p}_{\mathrm{n}}\right)$ unlikely true, by itself it gives me no evidence against it.

Things are not so simple for our second evidential fact. It is tempting to state it in the following way:

$\left(\mathbf{E}_{2} *\right)\left(\mathrm{p}_{1} \wedge \mathrm{p}_{2} \wedge \ldots \mathrm{p}_{\mathrm{n}}\right)$ provides me with sufficient evidence for the claim that 'there is at least one false claim in my book' $(\mathrm{F})$.

But this would be a mistake. $\left(E_{2}{ }^{*}\right)$ is false. This is because ${ }^{`} \mathrm{P}\left(\left(\mathrm{p}_{1} \wedge \mathrm{p}_{2} \wedge \ldots \mathrm{p}_{\mathrm{n}}\right) \mid \mathrm{F} \& \mathrm{k}\right)>\mathrm{P}\left(\left(\mathrm{p}_{1} \wedge \mathrm{p}_{2} \wedge\right.\right.$ $\left.\left.\ldots \mathrm{p}_{\mathrm{n}}\right) \mid \mathrm{k}\right)$ ' is false. Our ' $\mathrm{F}$ ' does not predict ' $\left(\mathrm{p}_{1} \wedge \mathrm{p}_{2} \wedge \ldots \mathrm{p}_{\mathrm{n}}\right)$ ' either. Suppose that ' $\mathrm{p}_{1}$ ' is the claim that 
'Napoleon lost the battle of Waterloo', and that ' $\mathrm{p}_{2}$ ' is the claim that 'Napoleon was French', and so on. The probability of these claims being true is not raised by the fact that 'there is at least one false claim in my book'. So ' $\left(\mathrm{p}_{1} \wedge \mathrm{p}_{2} \wedge \ldots \mathrm{p}_{\mathrm{n}}\right)$ ' is not evidence for ' $\mathrm{F}$ ' either and $\mathrm{E}_{2} *$ is false.

Our second evidential fact, therefore, needs a different interpretation. Stating it informally, I said that 'a large number of these claims, taken as a collection, is in fact sufficient evidence for that same belief'. The key to my evidence against $\left(\mathrm{p}_{1} \wedge \mathrm{p}_{2} \wedge \ldots \mathrm{p}_{\mathrm{n}}\right)$, notice, is not in the content of the individual propositions, either individually or as a conjunction, but rather in my taking them as a collection. The second evidential fact, in other words, is based not on $(\mathrm{p} \wedge \mathrm{q} \wedge \ldots \mathrm{z})$, but on something $(\mathrm{p} \wedge \mathrm{q} \wedge \ldots \mathrm{z})$ entails about itself: 'the set of propositions in my book is very large'. It is this fact that becomes salient when I consider not what the particular propositions say but rather consider them qua collection. So the second evidential fact is properly stated in the following way:

$\left(\mathbf{E}_{2}\right)$ The fact that 'the set of propositions in my book is very large' ( $\left.\mathrm{p}^{*}\right)$ provides me with sufficient evidence for the claim that 'there is at least one false claim in my book' (F).

And this seems true. It is plausible that $\mathrm{P}\left(\mathrm{p}^{*} \mid \mathrm{F} \& \mathrm{k}\right)>\mathrm{P}\left(\mathrm{p}^{*} \mid \mathrm{k}\right)$. Importantly, this is because I am only modestly fallible with respect to the content of my book, a fact captured by a subset of the propositions in my background knowledge ' $k$ '. Since I am fallible, I am liable to have made mistakes; but since I am not hopelessly fallible, I can reasonably expect to not make mistakes with a small amount of claims. So the claim that 'there is at least one false claim in my book' predicts that 'the set of propositions in my book is very large'. My chance of getting something wrong increases, that is, with the repeated opportunities for that unlikely mistake. ${ }^{11}$

We can now draw a general lesson from this case. We can say that non-cumulative inductive bases are produced when the fact that a collection of propositions is very large - a fact that is entirely independent of the content of the propositions in the collection-itself raises the probability of some hypothesis being true. This is what accounts for our evidence in the preface paradox. Our evidence, in this case, is still inductive since it provides probabilistic support that depends on a large amount of a certain item. Yet it is non-cumulative, since the sufficient evidential support offered by the collection of

11 A very similar analysis can be given for the lottery paradox [cf. Kyburg 1961]. Given the individually low chances of each ticket being the winner, the probability of my having a large number of lottery tickets is raised by the fact that I happen to have the winner. 
items therein does not depend on the accumulation of small bits of evidential support from each of these items individually. ${ }^{12}$

\section{The Collective Justification of P2}

Consider a key passage from Rowe [1979: 337-8] where he describes an instance of intense suffering experienced by a fawn during a forest fire:

But even if it should somehow be reasonable to believe [that there is a justifying reason for] the fawn's suffering, we must then ask whether it is reasonable to believe [that there is a justifying reason for] all the instances of seemingly pointless human and animal suffering that occur daily in our world... In the light of our experience and knowledge of the variety and scale of human and animal suffering in our world, the idea that none of this suffering [lacks a justifying reason] seems an extraordinarily absurd idea, quite beyond our belief. ${ }^{13}$

Despite the common interpretation of EAE as relying on enumerative induction, I hope you see the striking parallels between Rowe's suggestion in this passage and the preface paradox. He seems to be suggesting that even though we might be reasonable in believing of each instance of apparently pointless suffering that it is not in fact a case of pointless suffering, we are nonetheless not reasonable in believing of the collection of these instances that it does not contain at least one instance of pointless suffering. But these claims will seem paradoxical, of course, if we accept another plausible principle of aggregation (PE1 below). Call this the paradox of evil:

\section{The Paradox of Evil:}

PE1. If I reasonably believe that instance of apparently pointless suffering $a$ has a point, and I reasonably believe that instance of apparently pointless suffering $b$ has a point, then it is reasonable for me to believe that $(a \& b)$ has a point as well.

PE2. I reasonably believe that instance of apparently pointless suffering $a$ has a point, I reasonably believe that instance of apparently pointless suffering $b$ has a

\footnotetext{
12 There is nothing mysterious about non-cumulative evidence in general. Some of them are even more extreme than the inductive ones I am considering here. Otte [2000: 7], for example, draws on Carnap to show that 'It might be the case that evidence e disconfirms $\mathrm{H}$, evidence i disconfirms $\mathrm{H}$, any yet evidence e\&i confirms $\mathrm{H}$... pieces of evidence may individually disconfirm a hypothesis even though the conjunction of the evidence confirms it. Because of this, when we have a collection of evidence it is a mistake to look at the effect of pieces of evidence on a hypothesis individually'. See also Otte [2012: 129].

${ }^{13}$ I am translating talk of outweighing goods to talk of justifying reasons. The emphasis is original.
} 
point, ... I reasonably believe that instance of apparently pointless suffering $x$ has a point.

PE3. It is not reasonable for me to believe that $(a \& b \& \ldots x)$ has a point.

These three claims cannot all be true. But since we seem to see Rowe contemplating the possibility of PE2 and PE3 (even if he only begrudgingly grants PE2), perhaps we can resolve this tension by denying PE1. This would be rather plausible, I think, if the evidential features of the preface paradox we just discussed were also present in the case of our awareness of apparently pointless evil.

We have already seen in our discussion of sceptical theism that it is false that an instance of apparently pointless suffering is evidence for me that there is at least one instance of pointless suffering in the world. (Recall that I am granting this for the sake of argument.) This is especially so if, following Rowe's concession, we reasonably believe that there is a justifying reason for that particular instance. Many theists, in fact, may well find themselves in exactly this position, believing antecedently that God would not allow that particular evil otherwise. (Let us also grant the justifiability of this antecedent belief.) For them, it is just not the case that, upon carefully considering an instance of apparently pointless suffering and upon renewing their confidence that it has a point, the world then becomes more likely to have at least one instance of pointless suffering. It sounds absurd for them to say- just as absurd as in the preface paradox — that:

'I am confident there is a justifying reason for this instance of apparently pointless suffering; so I'm now a bit more confident that there is at least one instance of truly pointless suffering in the world'.

Evidence doesn't work that way. Nonetheless, this needs not prevent us from thinking that the collection of instances of apparently pointless suffering provides evidence- sufficient evidence, evenfor there being at least one instance of truly pointless suffering in the world. Evidence can work that way, as we have seen in the preface paradox, and it would work that way in this case, if we resolved the paradox of evil by rejecting PE1. The result would be that while an instance of apparently pointless suffering, considered individually, is no evidence for me that there is at least one instance of truly pointless suffering in the world (call this evidential fact $E_{3}$ ), a large number of these instances, taken as a collection, is in fact sufficient evidence for that same belief (call this evidential fact $E_{4}$ ). What these two evidential facts would reveal, in other words, is that considering the apparent pointlessness of $(a \& b \& \ldots x)$ provides me with sufficient evidence against believing that $(a \& b \& \ldots$ $x$ ) has a point, but not by way of the accumulation, by enumerative induction, of small bits of 
evidence provided individually by not seeing a point for $a$, and $b$, and so on. The apparently pointless evil in our world, that is, would produce yet another example of a non-cumulative inductive base. ${ }^{14}$

The question, of course, is whether $\mathrm{E}_{3}$ and $\mathrm{E}_{4}$ are true. We can state $\mathrm{E}_{3}$ more carefully in the following way:

(E) The fact that 'I see no point for instance of suffering a' provides me with no evidence for the claim that 'there is at least one instance of pointless suffering in the world'.

I am assuming that Sceptical Theism shows this to be true. In examining $\mathrm{E}_{4}$, however, let us notice that the key to my evidence for the pointlessness of $(a \& b \& \ldots x)$ is in my taking those instances as $a$ collection, and thereby focusing on something $(a \& b \& \ldots x)$ entails about itself: 'the amount of instances of apparently pointless suffering is very large'. We can then state $\mathrm{E}_{4}$ in the following way:

$\left(\mathbf{E}_{4}\right)$ The fact that 'the amount of instances of apparently pointless suffering is very large' provides me with sufficient evidence for the claim that 'there is at least one instance of pointless suffering in the world'.

And this seems true. What we need to keep in mind, once again, is our modest fallibility. Since I am fallible, I am liable to judge as pointless what turns out to have a point; but since I am not hopelessly fallible, I can legitimately expect to not be wrong about a large amount of these instances. My chance of getting something right increases, that is, with the repeated opportunities for that unlikely success. So while our fallibility prevents a single instance of apparently pointless suffering from giving us evidence of truly pointless evil, the modesty of that fallibility prevents a large amount of apparently pointless suffering from not giving us sufficient evidence for that same fact. Denying $\mathrm{E}_{4}$, therefore, is not on a par with the reasonable-sounding claims of sceptical theists regarding our limited access to the justifying facts; denying $\mathrm{E}_{4}$ is very much to say that we just don't have a clue about them. (More on this below.)

${ }^{14}$ Drawing parallels between the preface paradox and the paradox of evil requires a parallel assumption of independence: For a large number of instances of apparently pointless suffering $(a \& b \& \ldots x)$, the justifying reason for one is independent from the justifying reason for another. I find this assumption very plausible, but Otte [2013: 92] disagrees: 'Suppose there is a good reason for God to permit a certain earthquake to occur; given this, it is now more likely that there is a good reason for God to permit other earthquakes to occur, and more likely that there is a good reason to permit other events, such as hurricanes, to occur.' I find this quite incredible. Not only do I find the proposed justifying reasons (such as 'natural evil... is a result of God creating an orderly and predictable world', Ibid.) wholly unconvincing qua justifying reasons, I cannot see how any of them could serve as a unifying explanation for a large amount of the apparently pointless suffering that we see. 
This is significant. If our modest fallibility produces the relevant non-cumulative inductive base, then what we have here is a justification for P2 of EAE—call it the collective justification - that does not depend on (Instance) being true. Recall:

(Instance) S's seeing no justifying reason for an instance of suffering is evidence for $S$ that there is no justifying reason for at least some instances of suffering.

The new argument for P2 that has emerged sidesteps it entirely:

$\mathbf{P} \mathbf{2}_{1}$. We are only modestly fallible.

$\mathbf{P 2}$. If we are only modestly fallible, then, if we see no justifying reason for many instances of suffering in the world, we can legitimately expect to not be wrong about all of these instances.

$\mathbf{P 2}$. If we can legitimately expect to not be wrong about all of these instances, then it is reasonable to believe that there is no justifying reason for at least some of all that suffering.

P2. So, if we see no justifying reason for many instances of suffering in the world, then it is reasonable to believe that there is no justifying reason for at least some of all that suffering.

Nothing in this argument depends on the accumulation of small bits of evidential support from each particular instance of apparently pointless evil. This means that the evidential version of the problem of evil in general, and EAE in particular, are compatible with sceptical theism being true. ${ }^{15}$ By not depending on (Instance), the collective justification of P2 does not require a rejection of either (Expectation) or (Limitation). In fact, given its collective justification, P2 turns out to be even more modest than before: it not only respects the fact that apparently pointless instances of suffering are by themselves too weak to make reasonable someone's belief that there is no God, it also respects the sceptical theist's insistence that these instances, individually, offer no support at all for that belief. It is just that evil bears witness against God, we can borrow from Quine in saying, not individually but only as a corporate body.

\footnotetext{
15 It also shows that the evidential problem of evil does not depend on what Dougherty and Pruss [2014: 70] have called 'anomaly mongering,' where specific instances of evil are 'are selected precisely for the fact that they stand out as the hardest kinds of cases to justify'.
} 


\section{Sceptical Theism and the Paradox of Evil}

Sceptical theism is the claim that seeing no justifying reason for an instance of suffering is not evidence for us that it is not there. Given certain assumptions about how the evidence of evil accrues, as we saw in section 2, there seems to be a direct tension between sceptical theism and the evidential version of the problem of evil. Given alternative assumptions, however, as we saw in sections 3 and 4, this tension goes away. The remaining question is whether these alternative assumptions — what I have called the collective justification of P2—can be defended against a very natural challenge. I think they can.

The challenge I have in mind is to $\mathrm{E}_{4}$ : The fact that 'the amount of instances of apparently pointless suffering is very large' provides me with sufficient evidence for the claim that 'there is at least one instance of pointless suffering in the world'. This claim follows from $\mathrm{P} 22_{2}$ : given our only modest fallibility, if we see no justifying reason for many instances of suffering in the world, then we can legitimately expect to not be wrong about all of these instances. The challenge is defending these claims from a natural extension of one of the principles behind sceptical theism:

(Limitation*) We cannot expect to see a justifying reason for a large collection of instances of apparently pointless suffering, were such reason to be there.

(Limitation*) is nearly the very denial of $\mathrm{P} 22_{2}$. The problem is that, together with (Expectation), (Limitation*) entails a natural extension of sceptical theism itself:

Sceptical Theism*: Seeing no justifying reason for a large collection of instances of suffering is not evidence for us that it is not there.

And sceptical theism* is nearly the very denial of $\mathrm{E}_{4}$. So if sceptical theism* is true, then our modest fallibility cannot in fact deliver the collective justification of P2 discussed above.

But we have good reason to think that (Limitation*) is false. To the extent that we think that we are only modestly fallible with respect to justifying reasons, and not hopelessly fallible instead, we should resist the suggestion that we could look at so much suffering, of so many varying kinds, in so many different circumstances, to so many different beings, on going for so long, and be simply missing the justifying reasons behind each and every single one of them. That suggestion, to use Rowe's expression, seems 'extraordinarily absurd'. In this final section, however, I will argue that Christian 
theists, at least, have independent reasons for thinking that (Limitation*) is false. Only a bare bones type of theist, it turns out, is even positioned to consider this suggestion-but not without serious consequences either.

Recall that (Limitation) — the claim that we cannot expect to see a justifying reason for the instances of apparently pointless suffering, were such reasons to be there-turns on the plausibility of there being a cognitive gap between our epistemic position and God's. No Christian theist, however, should find plausible that this cognitive gap is absolutely unbridgeable, that we cannot expect to see God's justifying reasons for anything. The consequences of this maneuver are just too severe. First, one would lose any hope for a justified expectation that God's revelations of Himself (in person, through scripture, or via some angelic agent) are not lies-justified lies, of course, but lies whose justifying reasons remain beyond our ken. Second, and partly as a consequence of the eroding testimonial grounds, one would lose any hope for justified beliefs about the nature and character of God in general. Theists and non-theists have pressed these points. As Hudson [2014: 153-4] puts it, for example, taking ' $\mathrm{K}$ ' as 'any piece of alleged knowledge by revelation alone':

Do we have a guarantee that God would not deceive us about whether $K$ is true? Well, not if our being deceived about $\mathrm{K}$ is the kind of bad state of affairs for which there exists a compensating good or morally justifying reason. If there is a compensating good or morally justifying reason for such deception, God's essential perfect goodness is not in any way impugned by the deception—on the contrary, it may be morally obligatory to so deceive us" (emphasis original). ${ }^{16}$

The only way to prevent the complete erosion of justified beliefs about God and His behaviour is accepting that we can, at times, legitimately expect to see God's justifying reasons: we can understand why God has acted as He has, and the explanation for it does not turn Him into a monster. In other words, Christianity requires that we have partial cognitive access to God's reasons. Though we cannot expect to see all of God's reasons, we can nonetheless expect to see some of them. In particular, and at a minimum, Christian theists must accept that we can expect to see God's reasons whenever removing that legitimate expectation is in tension with other core beliefs about God's character and the nature of His relationship to us. What Christian theists must accept, in short, is that we are only modestly fallible with respect to God's justifying reasons in general.

16 See also Wielenberg [2010, 2014], and Almeida [2014]. 
This should not come as a surprise. After all, the evidential problem of evil is often deflected with the claim that one has not considered all of what the Christian believes about the nature of God, and about His intensions, reasons, and plans. As Bergmann and Rea [2005: 244] put it:

The sceptical theist strategy will not be deployed in a vacuum. Sceptical theists, after all, are theists. Thus, when they consider the bearing of sceptical theism on their moral practice, they will inevitably and quite sensibly do so in a way that takes account of other things that they believe.

My point here is merely an extension of this sentiment. The Christian theist can only use the cognitive gap defence as a shield against certain versions of the problem of evil if the weight of that shield (measured by the size of the cognitive gap) does not crush their other core beliefs as well. Call this the theistic problem of cognitive calibration.

In fact, paying close attention to the very same parent-child analogy that stands behind the sceptical theist's acceptance of (Limitation) provides us with some insight into which justifying reasons the theist should think that we can and cannot expect to see. As others have noted, the parent-child analogy has two sides. ${ }^{17}$ We see a different side of it depending on which aspect of the analogy we emphasize. One aspect of the analogy is the cognitive-gap that Wykstra and Bergmann and other sceptical theists have focused on. But another aspect of the same analogy_an aspect just as important for the Christian tradition as God's epistemic superiority-is the characterization of God's relation to us as akin to the relation between a loving parent and her child. But having justified beliefs about the loving nature of this relationship requires the legitimacy of certain expectations: it requires partial cognitive access to a more specific subset of God's justifying reasons; it requires our only modest (not hopeless) fallibility with respect to God's behaviour towards us. So while the Christian theist is allowed to suggest that we cannot expect to see all of God's reasons for allowing us to suffer as we do, on the strength of the parent-child analogy, she must do so without encroaching on the other expectations that the very same analogy legitimizes.

What, then, can we legitimately expect of God, given the belief that His relation to us is akin to that of a loving parent to her child? The sceptical theist seems correct in claiming that we cannot legitimately except to see God's justifying reasons for allowing each and every single instance of apparently pointless suffering. But the Christian theist must insist that we can legitimately expect to

17 See Dougherty [2012] and Wielenberg [2015] for discussions of the importance of the parent-child analogy for sceptical theism and for the Christian tradition in general. 
see God's justifying reasons for allowing the staggering amount of apparently pointless suffering in our world, taken as a whole. We can legitimately expect to see this, importantly, because a God who is akin to a loving parent would have revealed them to us. Just as loving parents do all they can to explain extended suffering to their children, a God who relates to us as a loving parent would do the same. ${ }^{18}$ The Christian theist, recall, cannot accept that we are so limited as to not be able to understand the reasons that we are required to understand in order to have certain specific justified beliefs about God's character in general and an accurate appreciation of the nature of His relationship to us. But that warrant is precisely what would be lost if we accepted that we cannot expect to know, or that we simply cannot understand, God's reasons for allowing so much suffering in our world. We cannot justifiably believe that God is akin to a loving parent if we cannot expect Him to behave as a loving parent does. A one-month old baby cannot expect to see or understand her parent's reasons, of course, but she also cannot (and certainly does not) justifiably believe that her parents are 'loving'. The cognitive capacities required for the latter, in other words, are sufficient to rule out the total cognitive limitations pictured in the former.

These considerations give the Christian theist independent reasons to join me in rejecting (Limitation*) and, consequently, sceptical theism*. Given the theistic problem of cognitive calibration, only the more moderate (Limitation), and sceptical theism proper, are compatible with the amount of expectations about God's reasons that the Christian theist must legitimize. This means that only the theist who rejects traditional Christian views about God's character and relationship to us can continue to push the natural challenge against the collective justification of P2 I outlined above. But this kind of bare bones theism comes with its own problem-of-evil-related difficulties: by abandoning traditional Christian views, the bare bones theist thereby loses the ability to resist the problematic moral consequences of sceptical theism that the Christian theist seems well positioned to deflect-consequences, moreover, that threaten a reductio. ${ }^{19}$ So the theist faces a dilemma: clinging to a bare bones version of theism makes way for the inductive justification of EAE by undermining sceptical theism; but shifting to Christian theism makes way for the collective justification of EAE by undermining sceptical theism* instead. There is sufficient evidence against God either way.

\section{Conclusion}

Many believe that the force of the evidential problem of evil depends on sceptical theism being false. This is only the case if we assume the inductive justification for P2. I have argued, however, that

18 See Rowe [1996: 276, 2001: 298-299, 2006: 87], and Wielenberg [2015: 306].

${ }^{19}$ See, for example, Jordan [2006], Maitzen [2009], and Sehon [2010]. 
there is an alternative justification available for it. According to the collective justification, P2 depends on a non-cumulative inductive base whereby the evidential import of the collection of instances of apparently pointless suffering is independent from the evidential import of the particular instances themselves. I have called this the paradox of evil, and identified our merely modest fallibility as its source. So long as we are not hopelessly fallible with respect to justifying reasonsand I have argued that even the Christian theist must accept that we are not—we can legitimately expect to see God's justifying reasons for so much apparently pointless suffering, were such a God and such reasons to really be there.

\section{References}

Adler, Jonathan 2002. Belief's Own Ethics. Cambridge: The MIT Press.

Almeida, Michael. J. 2014. Skeptical Theism and Undercutting Defeat, in Skeptical Theism: New

Essays, ed. Trent Dougherty and Justin P. McBrayer, Oxford: Oxford University Press: 115-131.

Benton, Matthew, John Hawthorne, and Yoaav Isaacs 2016. Evil and Evidence, in Oxford Studies

in Philosophy of Religion, Volume 7, ed. Jonathan Kvanvig, Oxford: Oxford University Press: 1-31.

Bergmann, Michael 2001. Skeptical Theism and Rowe's New Evidential Argument From Evil, Nous 35/2: 278-296.

Bergmann, Michael 2008. Skeptical Theism and the Problem of Evil, in The Oxford Handbook of Philosophical Theology, ed. Thomas Flint and Michael Rea, Oxford: Oxford University Press: 374399.

Bergmann, Michael and Michael Rea 2005. In Defence of Sceptical Theism: a Reply to Almeida and Oppy, Australasian Journal of Philosopby 83/2: 241-251.

Christensen, David 2004. Putting Logic in Its Place. Oxford: Oxford University Press.

Dougherty, Trent 2008. Epistemological Considerations Concerning Skeptical Theism, Faith and Philosophy 25/2: 172-176.

Dougherty, Trent 2012. Reconsidering the Parent Analogy: Unfinished Business for Sceptical Theists, International Journal for Philosophy of Religion 72/1: 17-25.

Dougherty, Trent and Alexander Pruss 2014. Evil and the Problem of Anomaly, in Oxford Studies in Philosophy of Religion, Volume 5, ed. Jonathan Kvanvig, Oxford: Oxford University Press: 49-88.

Draper, Paul 1989. Pain and Pleasure: An Evidential Problem for Theists, Nous 23/2: 331-50.

Draper, Paul 2009. The Problem of Evil, in The Oxford Handbook of Philosophical Theology, ed.

Thomas Flint and Michael Rea, Oxford: Oxford University Press: 332-51.

Foley, Richard. 1993. Working without a Net. Oxford: Oxford University Press. 
Howard-Snyder, Daniel 2009. Epistemic Humility, Arguments From Evil, and Moral Skepticism, in Oxford Studies in Philosophy of Religion, Volume 2, ed. Jonathan Kvanvig, Oxford University Press: $17-57$.

Howard-Snyder, Daniel and Michael Bergmann 2004. Evil Does Not Make Atheism More Reasonable than Theism, in Contemporary Debates in Philosopby of Religion, ed. Michael Peterson and Raymond VanArragon, Malden: Blackwell Publishers: 13-24.

Hudson, Hud 2014. "The Father of Lies," in Oxford Studies in Pbilosophy of Religion, Volume 5, ed. Jonathan Kvanvig, Oxford: Oxford University Press: 147-166.

Jordan, Jeff 2006. Does Skeptical Theism Lead to Moral Skepticism?, Philosophy and Phenomenological Research 72/2: 403-417.

Kaplan, Mark 1996. Decision Theory as Philosophy. Cambridge: Cambridge University Press.

Kim, Brian 2015. This Paper Surely Contains Some Errors, Philosophical Studies 172/4: 1013-1029.

Klein, Peter 1985. The Virtues of Inconsistency, The Monist 68/1: 105-135.

Kyburg, Henry 1961. Probability and the Logic of Rational Belief. Middletown: Wesleyan University Press.

Long, Todd R. 2014. Minimal Skeptical Theism, in Skeptical Theism: New Essays, ed. Trent Dougherty and Justin P. McBrayer, Oxford: Oxford University Press: 63-75.

Maitzen, Stephen 2009. Skeptical Theism and Moral Obligation, International Journal for Philosophy of Religion 65/2: 93-103.

Makinson, D.C. 1965. The Paradox of the Preface, Analysis 25/6: 205-207.

Otte, Richard 2000. Evidential Arguments From Evil, International Journal for Pbilosopby of Religion 48/1: 1-10.

Otte, Richard 2012. Comparative Confirmation and the Problem of Evil, in Probability in the Philosophy of Religion, ed. Jake Chandler and Victoria Harrison, Oxford: Oxford University Press: 127-143.

Otte, Richard 2013. A Carnapian Argument from Evil in The Blackwell Companion to the Problem of Evil, ed. Justin McBrayer and Daniel Howard-Snyder, Malden: Wiley Blackwell: 83-97.

Plantinga, Alvin 2000. Warranted Christian Belief. New York: Oxford University Press.

Pollock, John 1990. Nomic Probability and the Foundations of Induction. New York: Oxford University Press.

Rowe, William 1979. The Problem of Evil and Varieties of Atheism, American Philosophical Quarterly 16/4: 335-341.

Rowe, William 1991. Ruminations about Evil, Philosophical Perspectives 5: 69-88.

Rowe, William 1996. The Evidential Argument From Evil: A Second Look, in The Evidential Argument from Evil, ed. Daniel Howard-Snyder, Bloomington: Indiana University Press: 262- 85. 
Rowe, William 2001. Skeptical Theism: A Response to Bergmann, Nous, 35/2: 297-303.

Rowe, William 2006. Friendly Atheism, Skeptical Theism, and the Problem of Evil, International Journal for Philosophy of Religion 59/2: 79-92.

Ryan, Sharon 1991. The Preface Paradox, Philosophical Studies 64/3: 293-307.

Schechter, Joshua 2013. Rational Self-Doubt and the Failure of Closure, Philosophical Studies 163/2: 429-452.

Sehon, Scott 2010. The Problem of Evil: Sceptical Theism Leads to Moral Paralysis, International Journal for Philosophy of Religion 67/2: 67-80.

Tooley, Michael 2012. Inductive Logic and the Probability that God Exists: Farewell to Skeptical Theism, in Probability in the Philosophy of Religion, ed. Jake Chandler and Victoria Harrison, Oxford: Oxford University Press: 144-166.

van Inwagen, Peter 2001. The Argument from Particular Horrendous Evils, Proceedings of the American Catholic Philosophical Association 74: 65-80.

Wielenberg, Erik. 2010. Skeptical Theism and Divine Lies, Religious Studies, 46/4: 509-523.

Wielenberg, Erik. 2014. Divine deception, in Skeptical Theism: New Essays, ed. Trent Dougherty and Justin P. McBrayer, Oxford: Oxford University Press: 236-249.

Wielenberg, Erik 2015. The Parent-Child Analogy and the Limits of Sceptical Theism, International Journal for Philosophy of Religion 78/3: 301-314.

Wykstra, Stephen 1984. The Humean Obstacle to Evidential Arguments from Suffering: On Avoiding the Evils of Appearance, International Journal for the Philosopby of Religion 16/2: 73-93. Wykstra, Stephen 1996. Rowe's Noseeum Argument from Evil, in The Evidential Argument from Evil, ed. Daniel Howard-Snyder, Bloomington: Indiana University Press: 127-151.

Wykstra, Stephen and Timothy Perrine 2012. Foundations of Skeptical Theism: CORNEA, Counterfactuals, and Conditional Probabilities, Faith and Philosophy 29/4: 375-399. 